\title{
Source attribution of aerosol size distributions and model evaluation using Whistler Mountain measurements and GEOS-Chem-TOMAS simulations
}

\author{
S. D. D'Andrea ${ }^{1}$, J. Y. Ng ${ }^{2,1}$, J. K. Kodros ${ }^{1}$, S. A. Atwood ${ }^{1}$, M. J. Wheeler ${ }^{3}$, A. M. Macdonald ${ }^{3}$, W. R. Leaitch ${ }^{3}$, and \\ J. R. Pierce ${ }^{1}$ \\ ${ }^{1}$ Department of Atmospheric Science, Colorado State University, Fort Collins, CO, USA \\ ${ }^{2}$ W.M. Keck Science Department, Scripps College, Claremont, CA, USA \\ ${ }^{3}$ Air Quality Research Division, Atmospheric Science and Technology Directorate, Science and Technology Branch, \\ Environment Canada, Downsview, ON, Canada
}

Correspondence to: S. D. D’Andrea (sdandrea@atmos.colostate.edu)

Received: 16 June 2015 - Published in Atmos. Chem. Phys. Discuss.: 11 September 2015

Revised: 16 December 2015 - Accepted: 6 January 2016 - Published: 18 January 2016

\begin{abstract}
Remote and free-tropospheric aerosols represent a large fraction of the climatic influence of aerosols; however, aerosol in these regions is less characterized than those polluted boundary layers. We evaluate aerosol size distributions predicted by the GEOS-Chem-TOMAS global chemical transport model with online aerosol microphysics using measurements from the peak of Whistler Mountain, British Columbia, Canada (2182 m a.s.l., hereafter referred to as Whistler Peak). We evaluate the model for predictions of aerosol number, size, and composition during periods of free-tropospheric (FT) and boundary-layer (BL) influence at "coarse" $4^{\circ} \times 5^{\circ}$ and "nested" $0.5^{\circ} \times 0.667^{\circ}$ resolutions by developing simple FT/BL filtering techniques. We find that using temperature as a proxy for upslope flow (BL influence) improved the model-measurement comparisons. The best threshold temperature was around $2{ }^{\circ} \mathrm{C}$ for the coarse simulations and around $6{ }^{\circ} \mathrm{C}$ for the nested simulations, with temperatures warmer than the threshold indicating boundary-layer air. Additionally, the site was increasingly likely to be in cloud when the measured relative humidity (RH) was above $90 \%$, so we do not compare the modeled and measured size distributions during these periods. With the inclusion of these temperature and RH filtering techniques, the model-measurement comparisons improved significantly. The slope of the regression for $\mathrm{N} 80$ (the total number of particles with particle diameter, $D_{\mathrm{p}},>80 \mathrm{~nm}$ ) in the nested simulations increased from 0.09 to $0.65, R^{2}$ increased from 0.04 to 0.46 , and log-mean bias improved from
\end{abstract}

0.95 to 0.07 . We also perform simulations at the nested resolution without Asian anthropogenic emissions and without biomass-burning emissions to quantify the contribution of these sources to aerosols at Whistler Peak (through comparison with simulations with these emissions on). The longrange transport of Asian anthropogenic aerosol was found to be significant throughout all particle number concentrations, and increased $\mathrm{N} 80$ by more than $50 \%$, while decreasing the number of smaller particles because of suppression of new-particle formation and enhanced coagulation sink. Similarly, biomass burning influenced Whistler Peak during summer months, with an increase in N80 exceeding $5000 \mathrm{~cm}^{-3}$. Occasionally, Whistler Peak experienced N80 $>1000 \mathrm{~cm}^{-3}$ without significant influence from Asian anthropogenic or biomass-burning aerosol. Air masses were advected at low elevations through forested valleys during times when temperature and downwelling insolation were high, ideal conditions for formation of large sources of low-volatility biogenic secondary organic aerosol (SOA). This condensable material increased particle growth and hence N80. The low-cost filtering techniques and source apportionment used in this study can be used in other global models to give insight into the sources and processes that shape the aerosol at mountain sites, leading to a better understanding of mountain meteorology and chemistry. 


\section{Introduction}

Atmospheric aerosol particles impact human health, climate, and visibility. The magnitude of these impacts has a strong dependence on the size, concentration, and composition of the particles (Rosenfeld et al., 2008; Clement et al., 2009). These particles can impact climate by acting as seed particles for cloud formation, altering the brightness and/or the lifetime of clouds, or by scattering incoming solar radiation (e.g., Boucher et al., 2013). These impacts of aerosols on clouds and climate are driven by the number concentration of cloud condensation nuclei $(\mathrm{CCN})$, the particles large enough to serve as seeds for condensation of water to form cloud droplets (typically diameters larger than 30$100 \mathrm{~nm}$ ). Aerosol-cloud interactions are among the most uncertain properties in climate forcing estimations (Boucher et al., 2013). Aerosol size distributions, which are fundamental to aerosol-cloud interactions, evolve in the atmosphere as a direct result of microphysical processes such as condensation, coagulation, nucleation, primary emissions, and deposition. Quantitatively estimating the climatic effect of aerosols involves understanding the evolution of aerosol size distributions.

Atmospheric aerosols emitted from or formed near the Earth's surface may remain in the planetary boundary layer (BL) or may be transported to the free troposphere (FT). Aerosols in the FT tend to have longer lifetimes than aerosols in the BL as deposition rates are lower in the FT (Croft et al., 2014). Therefore, aerosols in the FT can be transported over great distances and can affect remote regions where local emissions may be minimal.

One important characteristic about measurements at highelevation mountain surface sites is that there are periods where they can be used to investigate and understand FT aerosols. However, these measurements are frequently influenced by a variety of aerosol sources including advection of BL air with upslope flow. The complexity of air-mass influences at high-elevation sites often makes measurements at these sites difficult to compare to simulations of regional and global models that do not resolve the sub-grid topography. While global models have been used to understand the processes shaping aerosols at mountaintop sites (e.g., Yu and Hallar, 2014), these models have resolution too coarse to explicitly resolve topographic meteorology effects of many mountain peaks. Synoptic meteorology, including advection and subsidence, influences the particles observed at mountain sites (Collaud Coen et al., 2011; Gallagher et al., 2011); however, one may expect chemical transport models to resolve these processes if synoptic meteorology is well represented. A major issue in comparing model simulations to mountaintop measurements is determining the appropriate model layer that accurately represents the high-elevation measurements under the various mountaintop conditions. Therefore, although measurements from these unique sites may be used to evaluate global models, we must first understand how to properly sample the model for comparison to the measurements.

The west coast of North America is routinely impacted by trans-Pacific transported aerosol. Long-term measurements have been taken by Environment Canada at Whistler Mountain, Whistler, British Columbia, at a site situated approximately $100 \mathrm{~km}$ from the west coast of Canada at the peak elevation of $2182 \mathrm{~m}$ a.s.l. $\left(50.06^{\circ} \mathrm{N}, 122.96^{\circ} \mathrm{W}\right.$ ) (hereafter referred to as Whistler Peak). Aerosol measurements at Whistler Peak have provided an understanding of the baseline aerosol number concentrations and trace gases, which are characteristic of the lower FT (Macdonald et al., 2011). These measurements often include contributions from Asian anthropogenic aerosol, which has been shown to influence concentrations of carbon monoxide (CO) and particulate matter along the west coast of North America (e.g., Husar et al., 2001; Jaffe et al., 2003; Bailey et al., 2000; Leaitch et al., 2009; Singh et al., 2009, and references therein), and can also lead to enhancements of ground-level ozone and CO concentrations (Macdonald et al., 2011; Jaffe et al., 1999). During the Northern Hemisphere summer, Whistler Peak also experiences influence from North American biomass-burning and biogenic secondary organic aerosol (SOA) that reaches the peak through upslope flows or deep boundary layers (e.g., Takahama et al., 2011). Global and regional models may help understand how these various sources contribute to aerosol size distributions at Whistler.

In this study, we use a global chemical transport model with online aerosol microphysics to investigate contributions to Whistler Peak aerosol from BL upslope flow, long-range transport of Asian anthropogenic aerosol, local biomassburning emissions, and other sources. We compare model simulations to measurements taken from Whistler Peak with the goals of (1) determining how to sample the model for comparison to mountaintop measurements and (2) understanding how various sources influence the aerosol size distributions at Whistler. In the following section, the measurements and model simulations used in this study are described. Section 3 describes the results, highlighting the data-filtering techniques, the comparison of measured and simulated particle number concentrations, and the influence of Asian anthropogenic emissions and biomass-burning aerosol on particle size distributions.

\section{Methods}

\subsection{Measurement description}

Continuous high-elevation surface-based aerosol size distribution measurements are taken by Environment Canada at Whistler Peak, located in the Coast Mountains in southwestern British Columbia (Fig. 1). The Whistler Peak site began continuous measurements of particle size distributions, trace gases (e.g., $\mathrm{O}_{3}, \mathrm{CO}, \mathrm{SO}_{2}, \mathrm{NO}_{x}$ ), and meteorologi- 


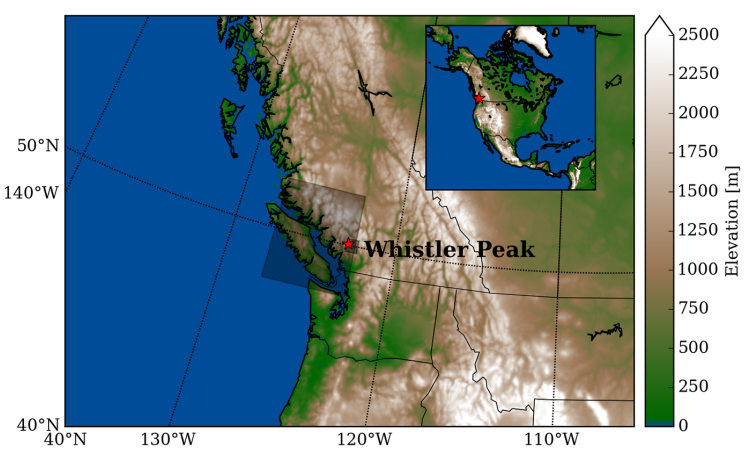

Figure 1. Location and elevation of Whistler Mountain, British Columbia $\left(50.06^{\circ} \mathrm{N}, 122.96^{\circ} \mathrm{W} ; 2182 \mathrm{~m}\right.$ a.s.1.). The Whistler Peak measurement site is denoted by a red star. The gray boxes indicate the boundaries of the simulated grid boxes used for modelmeasurement comparisons $\left(0.5^{\circ} \times 0.667^{\circ}\right.$ resolution for nested and $4^{\circ} \times 5^{\circ}$ resolution for coarse) .

cal parameters (temperature, pressure, relative humidity) in March 2002 (Macdonald et al., 2011), and intensive field campaigns were carried out in 2006 (e.g., Leaitch et al., 2009; McKendry et al., 2008) and most recently in 2010 with the Whistler Aerosol and Cloud Study (WACS2010, Pierce et al., 2012) during the summer of 2010 (21 June to 29 July). We use measurements over a 20 -month period from April 2010 to December 2011. Data coverage is shown in Fig. 2. Whistler Peak often resides in the lower FT (Gallagher et al., 2011) and therefore is an ideal location to provide a baseline of aerosol number concentrations and trace gases for the lower FT, and also to investigate the influence of long-range trans-Pacific transport of Asian anthropogenic emissions. The high-elevation Whistler Peak site is also ideal to investigate influences of local pollution sources such as biomass-burning aerosols that may appear in the summer during upslope flow or periods when the BL develops fully to include the peak. In this study we focus on particle size distributions and use meteorological measurements to compare to model simulations to measurements taken at Whistler Peak. For detailed descriptions of instrumentation at Whistler Peak, refer to Macdonald et al. (2011).

\subsection{Model description}

In this study, the Goddard Earth Observing System chemical transport model, GEOS-Chem (http://geos-chem.org), combined with the TOMAS online aerosol microphysics module (GEOS-Chem-TOMAS) as described in D'Andrea et al. (2013), is used to simulate aerosol number concentrations. The sensitivity to Asian anthropogenic aerosols and biomassburning aerosols is also tested through additional simulations. GEOS-Chem-TOMAS uses GEOS-Chem version 9.02 with $4^{\circ}$ latitude by $5^{\circ}$ longitude horizontal resolution for coarse simulations, and version 9.02 with $0.5^{\circ}$ latitude by $0.667^{\circ}$ longitude horizontal resolution for nested simula- tions (to be described in more detail in Sect. 2.3). GEOSChem-TOMAS uses 47 vertical layers from the surface to $0.01 \mathrm{hPa}$, and meteorological inputs from the GEOS5 reanalysis (http://gmao.gsfc.nasa.gov). In GEOS-Chem-TOMAS, aerosol size distributions are simulated using 15 size sections from $3 \mathrm{~nm}$ to $10 \mu \mathrm{m}$. Nucleation rates are predicted using ternary homogeneous nucleation (Napari et al., 2002) tuned globally by a factor of $10^{-5}$ (Westervelt et al., 2013). Ternary nucleation is used when $\mathrm{NH}_{3}$ mixing ratios are greater than $0.1 \mathrm{pptv}$; otherwise, nucleation rates are predicted by binary homogeneous nucleation (Vehkamäki et al., 2002). While these classical nucleation schemes do not get nucleation rates correct for the right reason, the scaled Napari scheme estimated nucleation rates within a factor of 5 and the annual number of nucleation days within $20 \%$ at five measurement sites in Westervelt et al. (2013). The choice of nucleation scheme impacts aerosol number concentrations, particularly at smaller sizes (Yu et al., 2010), and thus our choice of nucleation scheme has some bearing on our results here. Biomass-burning emissions are simulated from the Global Fire Emissions Database 3-hourly fire fractions (GFED3) (Mu et al., 2011). The primary black carbon and organic carbon emission size distribution is assumed to be a lognormal distribution with a geometric mean diameter of $100 \mathrm{~nm}$, consistent with field measurements of biomassburning smoke within the first hour since emission (Janhäll et al., 2010), although larger diameters may be more appropriate for some fires once sub-grid aging has occurred (Sakamoto et al., 2015). The density is assumed to be 2200 and $1400 \mathrm{~kg} \mathrm{~m}^{-3}$ for black carbon and organic carbon, respectively (Pierce et al., 2007). All simulations include an additional $100 \mathrm{Tg} \mathrm{yr}^{-1}$ of anthropogenically enhanced secondary organic aerosol (SOA), spatially correlated with anthropogenic carbon monoxide emissions as per Spracklen et al. (2011) and D'Andrea et al. (2013). SOA is assumed to be effectively non-volatile, with an average saturated vapor pressure, $C^{*}$, of less than approximately $10^{-3} \mu \mathrm{g} \mathrm{m}^{-3}$ (Pierce et al., 2011). This is consistent with kinetic, gas-phasediffusion-limited growth with condensation proportional to the Fuchs-corrected aerosol surface area as per D' Andrea et al. (2013). A complete description of emissions is provided in Stevens and Pierce (2014). Simulations were run from April 2010 through December 2011 with 1-month spin-up from a pre-spun-up restart file.

The surface layer in the simulated $4^{\circ} \times 5^{\circ}$ grid box (Fig. 1) encompassing Whistler Peak has a mean elevation of approximately $600 \mathrm{~m}$ a.s.l., and the surface layer in the simulated $0.5^{\circ} \times 0.667^{\circ}$ grid box (Fig. 1) encompassing Whistler Peak has a mean elevation of approximately $1290 \mathrm{~m}$ a.s.l.; however, Whistler Peak resides at an elevation of $2182 \mathrm{~m}$ a.s.l. (the simulated grid boxes includes mountainous regions, oceanic regions and urban cities such as Vancouver, British Columbia). This implies that the appropriate model layer to represent Whistler Peak would be the layer corresponding to approximately $1580 \mathrm{~m}$ above the modeled ground level 


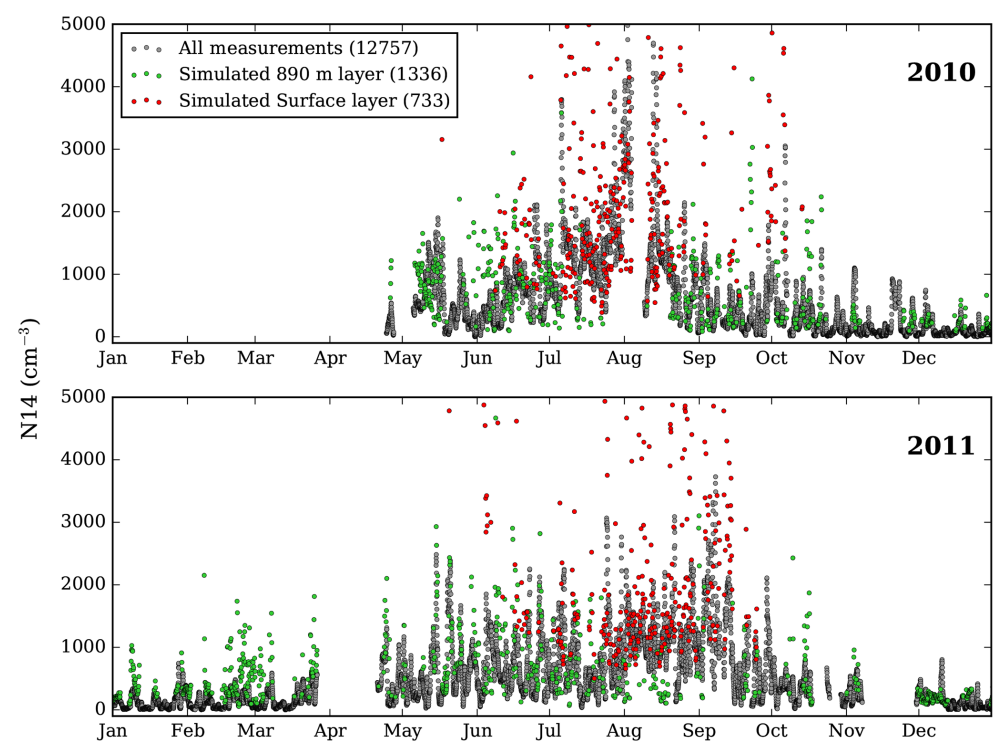

Figure 2. Time series of N14 (the total number of particles with particle diameter, $D_{\mathrm{p}},>14 \mathrm{~nm}$ ) for all measurements (black), and the temperature- and RH-filtered $890 \mathrm{~m}$ simulated layer (green) and surface layer (red). The bracketed number in the legend corresponds to the total number of data points for each condition.

in the coarse simulations and $890 \mathrm{~m}$ above the modeled ground level in the nested simulations. While GEOS-Chem does have vertical mixing for the resolved BL and synoptic/convective mixing between the BL and FT, it does not resolve sub-grid vertical transport due to topographic and upslope flows. Therefore, in order to represent the influence of $\mathrm{BL}$ air at sub-grid-scale terrain, conditions were developed to select the model level appropriate for the site conditions and are described in Sect. 3.2.

\subsection{Description of simulations}

We test the sensitivity of aerosol size distributions in GEOSChem-TOMAS to (a) the removal of Asian anthropogenic emissions and (b) the removal of biomass-burning emissions. Simulations are summarized in Table 1 . In all simulation names, the $\mathrm{C}$ indicates coarse simulations $\left(4^{\circ} \times 5^{\circ}\right.$ resolution). The BASE and BASE_C simulations include all emissions from GEOS-Chem-TOMAS as described in Stevens and Pierce (2014). The noAsia and noAsia_C simulations remove anthropogenic $\mathrm{SO}_{2}, \mathrm{NH}_{3}$, anthropogenic organic aerosol (including the anthropogenically enhanced SOA from D'Andrea et al. (2013) and elemental carbon from India, China, and southeastern Asia following the domain covered in Streets et al. (2003). The noAsia simulations do not mask biogenic SOA and other natural primary emissions. The noBioB and noBioB_C simulations mask all biomassburning emissions globally, while all other emission sources remain unchanged.
Table 1. Summary of the GEOS-Chem-TOMAS simulations used in this study. Note that $C$ indicates coarse simulations $\left(4^{\circ} \times 5^{\circ}\right)$.

\begin{tabular}{llll}
\hline Simulation & Resolution & $\begin{array}{l}\text { Asian } \\
\text { anthropogenic } \\
\text { emissions }\end{array}$ & $\begin{array}{l}\text { Biomass- } \\
\text { burning } \\
\text { emissions }\end{array}$ \\
\hline BASE_C & $4^{\circ} \times 5^{\circ}$ & yes & yes \\
noAsia_C & $4^{\circ} \times 5^{\circ}$ & no & yes \\
noBioB_C & $4^{\circ} \times 5^{\circ}$ & yes & no \\
BASE & $0.5^{\circ} \times 0.667^{\circ}$ & yes & yes \\
noAsia & $0.5^{\circ} \times 0.667^{\circ}$ & no & yes \\
noBioB & $0.5^{\circ} \times 0.667^{\circ}$ & yes & no \\
\hline
\end{tabular}

\section{Results and discussion}

\subsection{Filtering model and measurement data}

Figure $3 \mathrm{a}$ and $\mathrm{b}$ show $1: 1$ plots comparing measured and simulated N14 and N80 (the total number of particles with particle diameter, $D_{\mathrm{p}},>14 \mathrm{~nm}$ and $D_{\mathrm{p}}>80 \mathrm{~nm}$, respectively) using only the model surface layer (averaged elevation of $600 \mathrm{~m}$ a.s.1.) at the coarse resolution. All metrics from Fig. 3 are summarized in Table 2. In these comparisons, when using the model surface level only (panels a and $b$ ), the model consistently overpredicts N14 during times with low measured number concentrations (e.g., $\mathrm{N} 14<100 \mathrm{~cm}^{-3}$ ), and marginally underpredicts during more polluted conditions (e.g., $\mathrm{N} 14>1000 \mathrm{~cm}^{-3}$ ), with a slope of 0.11 in the linear regression. Also, comparisons with N80 show slightly improved but similar conclusions with overpredictions during cleaner conditions, marginal underprediction during more 
Table 2. Summary of the slope of the linear regression $(m)$, correlation $\left(R^{2}\right)$, and log-mean bias (LMB) for coarse and nested simulations. These statistics are found by comparing the average values of the aerosol number concentrations during the measurement period to measurements at Whistler Peak. Bolded numbers represent the best statistical result between all simulations.

\begin{tabular}{|c|c|c|c|c|c|c|}
\hline \multirow[t]{2}{*}{ Coarse } & \multicolumn{2}{|c|}{$m$} & \multicolumn{2}{|c|}{$R^{2}$} & \multicolumn{2}{|c|}{ LMB } \\
\hline & N14 & N80 & N14 & N80 & N14 & N80 \\
\hline surface layer & 0.11 & 0.14 & 0.05 & 0.17 & 0.61 & 0.67 \\
\hline $1580 \mathrm{~m}$ layer & 0.21 & 0.27 & 0.19 & 0.36 & 0.06 & -0.01 \\
\hline $2{ }^{\circ} \mathrm{C} T$ and $90 \% \mathrm{RH}$ filter & 0.44 & 0.54 & 0.30 & 0.44 & 0.08 & -0.03 \\
\hline Nested & N14 & N80 & N14 & N80 & N14 & N80 \\
\hline surface layer & 0.09 & 0.09 & 0.02 & 0.04 & 0.91 & 0.95 \\
\hline $890 \mathrm{~m}$ layer & 0.27 & 0.26 & 0.19 & 0.24 & 0.23 & 0.26 \\
\hline $6^{\circ} \mathrm{C} T$ and $90 \%$ RH filter & 0.65 & 0.65 & 0.4 & 0.46 & 0.17 & 0.07 \\
\hline
\end{tabular}

polluted conditions, and a slope of 0.14 in the linear regression. The nested simulations yield similar results (Fig. $3 \mathrm{~g}$ and $h$ ), with overpredictions of N14 and N80 in cleaner conditions and underpredictions of N14 and N80 in more polluted conditions. Therefore, it is clear that simulated particle number concentrations in the model surface level alone do not accurately represent the measurements at Whistler Peak under all meteorological conditions. Figure $3 \mathrm{c}$ and $\mathrm{d}$ show $1: 1$ plots comparing measured and simulated N14 and N80 using only the $1580 \mathrm{~m}$ model layer (2200 m a.s.l.) at the coarse resolution, which corresponds to the actual elevation at Whistler Peak. The $1580 \mathrm{~m}$ level produces marginally improved but similar conclusions to the model surface level. GEOS-Chem-TOMAS consistently overpredicts N14 during clean conditions and underpredicts N14 during more polluted conditions, with a slope of 0.21 . Similarly, N80 is overpredicted during clean conditions and underpredicted during more polluted conditions when assuming the $1580 \mathrm{~m}$ level, with a slope of 0.27 . The nested simulations once again yield similar results (Fig. 3i and j), overpredicting N14 and N80 in cleaner conditions, and underpredicting N14 and N80 in more polluted conditions. A common trait between the surface and $1580 \mathrm{~m}(890 \mathrm{~m})$ level comparisons is the large model overpredictions during clean measurements. However, with both the surface level and the $1580 \mathrm{~m}(890 \mathrm{~m})$ level, there may be conditions where the model predicts the correct particle number concentration. Even though the metrics for the coarse simulations are slightly better in some cases than the nested simulations, all of the metrics were overall very poor. Therefore, we must use meteorological conditions to determine how best to compare the model to measurements.

A characteristic of Whistler Peak is that the measurement site frequently experiences in-cloud conditions (Macdonald et al., 2011). Previous work showed that measurements with relative humidity $(\mathrm{RH})>90 \%$ at the Whistler Peak station corresponded closely to cloudy conditions at the site. When Whistler Peak is in cloud, the measured aerosol size distributions can not be used for model comparison, because some of the particles will be in cloud droplets, either by activation or by diffusive collection. Therefore, the data have been filtered based on the ambient relative humidity - i.e., data are not included in the measurement-model comparison when the measured RH is $>90 \%$. Although use of $90 \%$ as the threshold value is an estimate, the identification of clouds by this criterion agrees with the visual confirmation of clouds through regular site photographs. This RH filter significantly reduces the number of points where the model consistently overpredicts the number of particles during low number concentration conditions. This can be seen in Fig. 4, which shows a histogram of the frequency of data points as a function of measured N80 (Fig. 4a for coarse simulations, Fig. $4 \mathrm{~b}$ for nested simulations), where the dark-gray bars are with the RH filter off and the blue bars are with the $90 \% \mathrm{RH}$ filter applied. If a particle is activated, it will not be measured and therefore $\mathrm{N} 80$ can reach very low number concentrations $\left(\mathrm{N} 80<1 \mathrm{~cm}^{-3}\right.$ ), whereas particles with $D_{\mathrm{p}}$ between 14 and $80 \mathrm{~nm}$ might not activate and will be measured. With the RH filter applied, the number of points with measured $\mathrm{N} 80<100 \mathrm{~cm}^{-3}$ is reduced most strongly for all simulations, and nearly all the points with measured $\mathrm{N} 80<10 \mathrm{~cm}^{-3}$ are removed. Therefore, applying the $\mathrm{RH}$ filter removes in-cloud conditions when we expect measurements to be biased low. It is likely that the RH $>90 \%$ filter eliminates some data that were not during cloudy conditions, as some of the data with higher measured N80 are eliminated. We tested other critical RH values as filters, but moving to larger RH values allowed cases with low N80 (e.g., $<5 \mathrm{~cm}^{-3}$ ) to be included.

Whistler Peak may be encompassed by an air mass originating from lower altitudes if the BL is very deep (over $1.5 \mathrm{~km}$ ) or if there is upslope flow. To separate conditions of upslope flow or deep BL from FT conditions, we also define a threshold temperature. When the measured temperature exceeds the threshold temperature, upslope flow is assumed and the model surface layer is used. When the measured temperature is less than the threshold temperature, then FT air is assumed at the peak and the $1580 \mathrm{~m}(890 \mathrm{~m})$ model layer is 

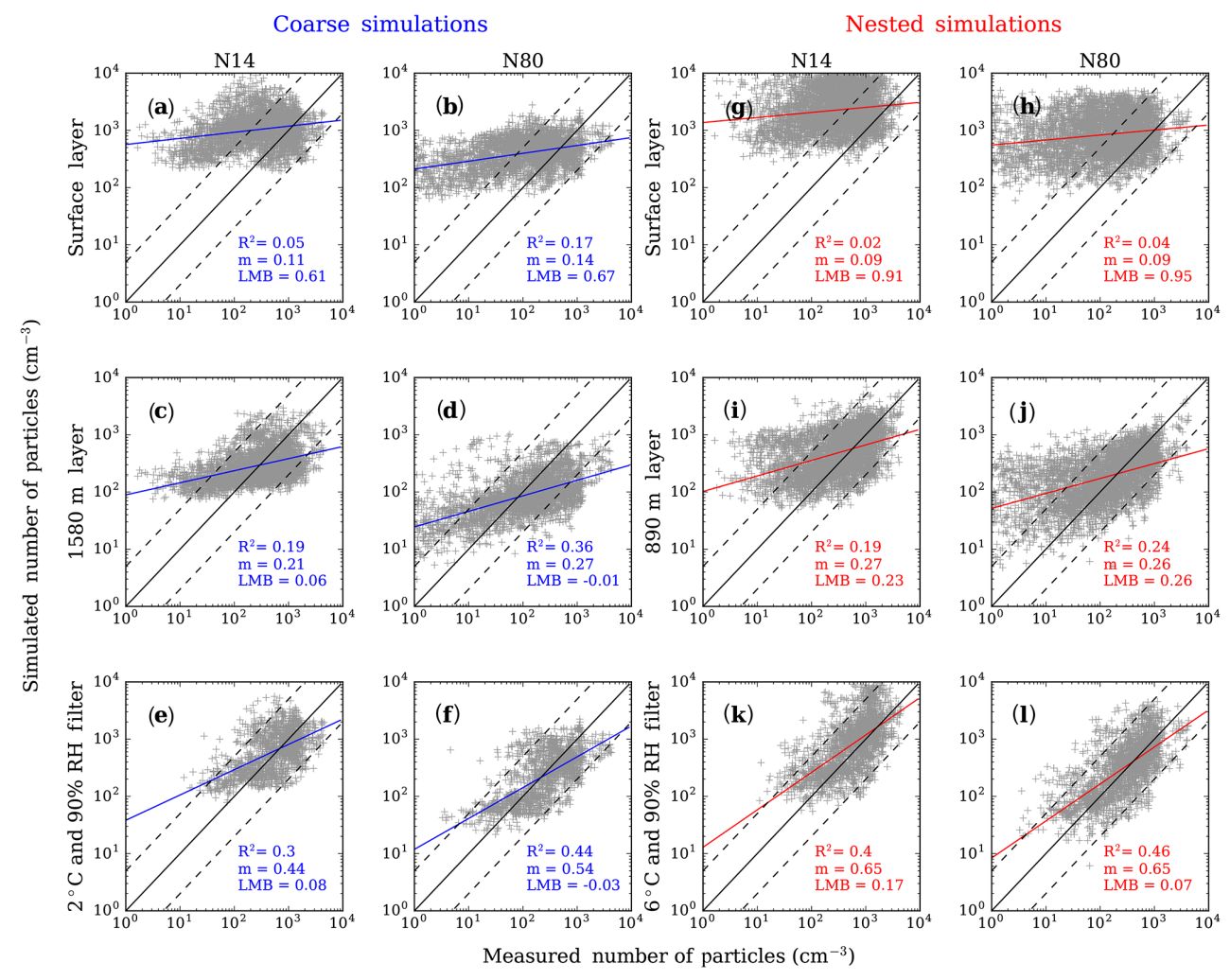

Figure 3. One-to-one plots of measured and simulated N14 and N80 (the total number of particles with particle diameter, $D_{\mathrm{p}},>14 \mathrm{~nm}$ and $>80 \mathrm{~nm}$, respectively) for the nested simulations $\left(0.5^{\circ} \times 0.667^{\circ}, \mathbf{g}-\mathbf{l}\right)$ and coarse simulations $\left(4^{\circ} \times 5^{\circ}\right.$, a-f $)$. Statistics are colored red for nested simulations and blue for coarse simulations. Panels (a), (b), (g), and (h) represent the model surface layer, panels (c), (d), (i) and (j) represent model level corresponding to the actual height of Whistler Mountain peak ( $890 \mathrm{~m}$ layer for nested and $1580 \mathrm{~m}$ for coarse), and panels (e), (f), (k), and (l) are for the filtered combination. For the filtered combination, surface layer in the nested (coarse) simulation is selected when measured temperature exceeds $6{ }^{\circ} \mathrm{C}\left(2{ }^{\circ} \mathrm{C}\right), 890 \mathrm{~m}(1580 \mathrm{~m})$ layer is selected otherwise; points with $>90 \%$ relative humidity are removed to reduce in-cloud sampling. The red and blue lines indicate the regression line, solid black line indicates the ideal $1: 1$ line, and the dashed black lines indicate the $1: 5$ and $5: 1$ lines.

used. Various temperature thresholds were imposed for determining which model level to use. The temperature-filtered simulated particle size distribution that most accurately represents the measured particle size distribution based on correlation statistics summarized in Table 3 is when a threshold of about $2^{\circ} \mathrm{C}$ is assumed for the coarse simulations, and about $6^{\circ} \mathrm{C}$ for the nested simulations. That is, when the measured temperature at Whistler Peak is less than $2{ }^{\circ} \mathrm{C}\left(6^{\circ} \mathrm{C}\right)$, the $1580 \mathrm{~m}(890 \mathrm{~m})$ model layer is assumed and when the measured temperature is greater than $2{ }^{\circ} \mathrm{C}\left(6^{\circ} \mathrm{C}\right)$, the model surface layer is assumed. We note, however, that due to uncertainty in these best threshold temperatures from (1) different metrics giving best values at different temperatures and (2) model errors, there is likely no significance in the different threshold temperatures for the two different resolutions. As temperature is a simple proxy for boundary-layer influence, interannual variability in synoptic conditions at Whistler Peak beyond the measurement period in this study may lead to variability in an ideal threshold temperature between years. The observed mean particle number size distri- butions and various temperature-dependent simulated mean particle number size distributions for the duration of the measurement period are shown in Fig. 5a and b (coarse and nested, respectively). When using the filtered data and assuming only the model surface level (black dotted line), the predicted total number of particles is much too high for all simulations, and when assuming the $1580 \mathrm{~m}(890 \mathrm{~m})$ level (black dashed line), the number of small particles is overpredicted and the number of particles larger than roughly $30 \mathrm{~nm}$ is underpredicted.

Previous studies have used other methods to represent BL influence at Whistler Peak and other high mountaintop sites; however, these methods were used to identify days of BL influence, whereas we seek to sort simulated hourly time points into either BL or FT influence. We therefore synthesized the following methods to test an alternate filter based on N14, rather than attempting to apply each method. Obrist et al. (2008) and Weiss-Penzias et al. (2006) noted diurnal water vapor cycles as indicators of BL influence at Colorado and Oregon mountain peaks; in New Hampshire, Grant 

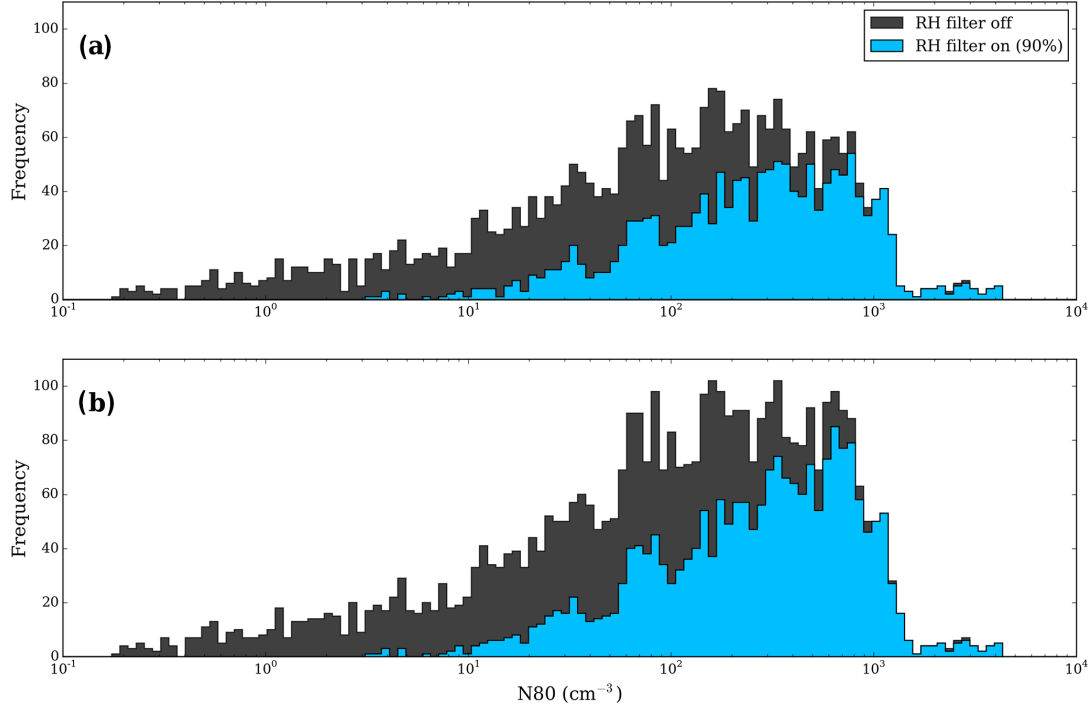

Figure 4. Histogram of the frequency of data points as a function of measured N80 (the total number of particles with particle diameter, $D_{\mathrm{p}}$, $>80 \mathrm{~nm})$, for $(\mathbf{a})$ coarse simulations $\left(4^{\circ} \times 5^{\circ}\right)$ and $(\mathbf{b})$ nested simulations $\left(0.5^{\circ} \times 0.667^{\circ}\right)$. The dark-gray bars are with the relative humidity filter off and the blue bars are with the $90 \%$ relative humidity filter applied.

Table 3. Summary of the slope of the linear regression $(m)$, correlation $\left(R^{2}\right)$, and log-mean bias (LMB) for different temperature cutoffs for coarse and nested simulations. These statistics are found by comparing the simulated aerosol number concentrations during the measurement period to measurements at Whistler Peak for various temperature cutoffs with the $90 \%$ RH filtering included. Bolded numbers represent the best statistical result between all simulations.

\begin{tabular}{lrrrrrr}
\hline Coarse & $-3{ }^{\circ} \mathrm{C}$ & $0{ }^{\circ} \mathrm{C}$ & $2{ }^{\circ} \mathrm{C}$ & $3{ }^{\circ} \mathrm{C}$ & $4{ }^{\circ} \mathrm{C}$ & $6{ }^{\circ} \mathrm{C}$ \\
\hline$R^{2}$ & 0.35 & 0.40 & $\mathbf{0 . 4 4}$ & 0.43 & 0.43 & 0.43 \\
$m$ & 0.48 & 0.51 & $\mathbf{0 . 5 4}$ & 0.53 & 0.53 & 0.51 \\
LMB & 0.08 & $\mathbf{0 . 0 2}$ & -0.03 & -0.06 & -0.11 & -0.18 \\
\hline Nested & $3{ }^{\circ} \mathrm{C}$ & $5^{\circ} \mathrm{C}$ & $6^{\circ} \mathrm{C}$ & $7{ }^{\circ} \mathrm{C}$ & $9{ }^{\circ} \mathrm{C}$ & $11^{\circ} \mathrm{C}$ \\
\hline$R^{2}$ & 0.43 & 0.45 & $\mathbf{0 . 4 6}$ & 0.44 & 0.42 & 0.41 \\
$m$ & $\mathbf{0 . 6 7}$ & 0.66 & 0.65 & 0.62 & 0.58 & 0.53 \\
LMB & 0.18 & 0.11 & 0.07 & 0.05 & $\mathbf{0 . 0 0}$ & -0.03 \\
\hline
\end{tabular}

et al. (2005) identified days with BL influence using early morning minimum and afternoon maximum temperatures. Moreover, daily total particle number (condensation nuclei, $\mathrm{CN}$, in our case, N14) increases indicated BL uplift in Hawaii (Bodhaine, 1996) and Switzerland (e.g., Baltensperger et al., 1997). At Whistler Mountain, Macdonald et al. (2011) used temperature data from multiple vertical levels on the mountain to define a stability index as an indicator of BL influence; however, many of the temperature-measurement sites used in Macdonald et al. (2011) were not operational during our time period. Gallagher et al. (2011) described the frequency of BL influence at Whistler by evaluating how well the change in $\mathrm{CN}$ concentration throughout each day adhered to a typical sinusoidal pattern, noting that confidence in the influence of vertical transport is higher on days when $\mathrm{CN}$ correlates strongly with water vapor.

We tested a filter based on $\mathrm{CN}$ changes throughout the day on simulated Whistler measurements informed by these studies. Though some of the studies discussed above used water vapor, we used CN because Gallagher et al. (2010) found that $\mathrm{CN}$ was a more robust indicator of $\mathrm{BL}$ influence at Whistler. We identified BL influence days using increasing $\mathrm{CN}$ concentration from morning to midday (09:00-11:00 average $<11: 00-13: 00$ average $<13: 00-15: 00$ average) and selected 11:00 to 17:00 local time as BL influence hours within those days when we applied the surface model layer. We assumed all other time points represented the FT and used the $2.5 \mathrm{~km}$ model layer for those times. However, this filter method was less successful than the temperature filter, with $R^{2}=0.04$ and slope $=0.15$ for regression of simulated versus observed N80 particles (not shown). The correlation did not improve when we relaxed the parameters: $R^{2}$ was 0.01 and the slope was 0.07 for the N80 regression when we used $\mathrm{CN}$ increase from 09:00-11:00 to $13: 00-15: 00$ as the BL day criterion (disregarding 11:00-13:00) and no daytime restriction on BL hours.

The low performance of this CN-cycle method could be due to overly strict criteria; the BL could influence peak aerosol on days when $\mathrm{CN}$ does not increase from morning to early afternoon. In particular, during periods of sustained high-pressure systems, for example when the site was influenced by the BL throughout both day and night, this $\mathrm{CN}$ filter would not result in identifying the BL influence. Also, Whistler frequently observes new-particle formation events. Gallagher et al. (2011) estimated that the new-particle forma- 

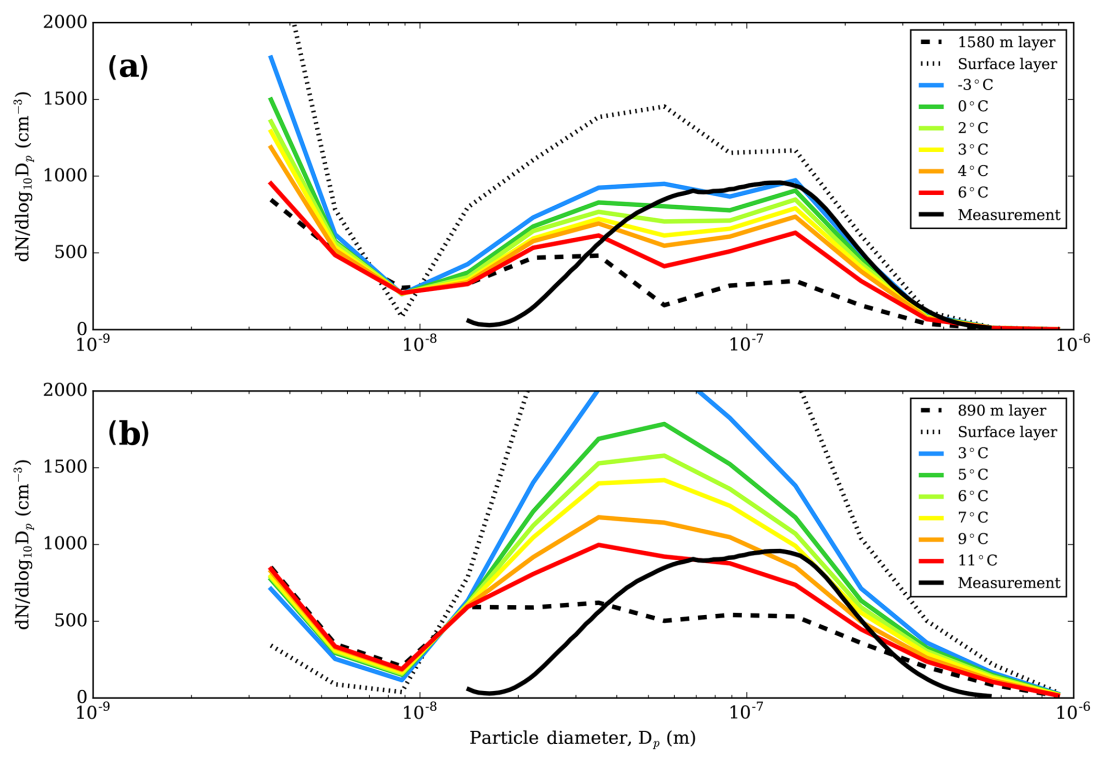

Figure 5. Observed and temperature-dependent simulated mean particle number size distributions for the measurement period for the (a) coarse simulations $\left(4^{\circ} \times 5^{\circ}\right)$ and (b) nested resolution $\left(0.5^{\circ} \times 0.667^{\circ}\right)$. The solid black line indicates the measured data, the black dashed line indicates the $890 \mathrm{~m}$ simulated layer, the black dotted line indicates the simulated surface layer, and the colored lines indicate various temperature thresholds, where cool colors indicate colder threshold values and warmer colors indicate warmer threshold values.

tion at Whistler was generally correlated with upslope flow and BL air. However, it is likely that not all new-particle formation events are associated with BL air and thus would contribute error to using $\mathrm{CN}$ as a classification of BL air. Thus, the methods described above to identify days of BL influence from observed water vapor, timing of temperature extrema, and $\mathrm{CN}$ increases may not be robust for sorting simulated hourly time points into either BL or FT influence as we do here.

The RH filter combined with the temperature-dependent model level assumption improves comparisons with measurements. Figure $3 \mathrm{e}$ and $\mathrm{f}$ include the RH filter and the temperature filter in the coarse simulated and measured comparison of N14 and N80. With these two filters included in the analysis, the slope of the regression for N14 and N80 both significantly improve ( 0.44 and 0.54 , respectively) as well as the $R^{2}(0.3$ and 0.44 , respectively). Similar results are found for the nested simulations (Fig. 3k and 1), with the slope improving even further to 0.65 for both $\mathrm{N} 14$ and $\mathrm{N} 80$, and the $R^{2}$ improves to 0.4 for N14 and 0.46 for N80. A small positive bias still remains in the simulated number concentrations. However, the log-mean bias for N14 and N80 improved from 0.61 and 0.67 to 0.08 and -0.03 , respectively, in the coarse simulations, and from 0.91 and 0.95 to 0.17 and 0.07 , respectively, in the nested simulations (Table 2). For the following sections, only the nested simulations with these best temperature and $\mathrm{RH}$ filters will be used.

\subsection{Time series and data density}

In this section, we address the seasonal cycle of data availability and completeness once the filters have been applied. Figure 2 shows a time series of N14 for all measurements (black points), and the temperature and RH filtered points are shown in green when the $890 \mathrm{~m}$ simulated layer is selected and red when the surface simulated layer is selected from the nested simulations. Times where black points exist but no red or green points exists show that the model data have been filtered using RH for in-cloud conditions. Periods where there are no points are time periods where the scanning mobility particle sizer was not operating at Whistler. The bracketed number in the legend corresponds to the total number of data points for each condition. There are clear seasonal trends in N14 at Whistler Peak, with high particle number concentrations during the summer months, and relatively low particle number concentrations during the winter months. The summer maximum is due in part to the advection of BL air due to upslope flow to the peak as well as influence from biomass burning during the Northern Hemisphere boreal forest fire season, as we will show. For the period of July through September, $77 \%$ of the points are identified as BL in 2010 and $65 \%$ in 2011. For the period December 2010 through February 2011, $100 \%$ of the points are identified as FT. 

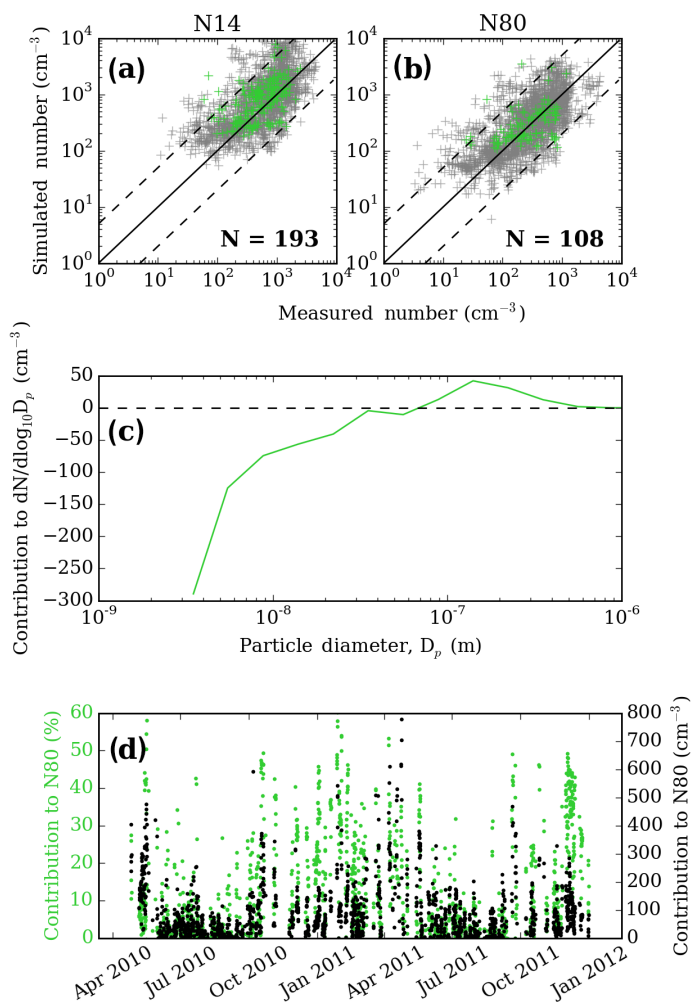

Figure 6. One-to-one plots for measured and simulated (nested resolution) (a) N14 and (b) N80, where the gray crosses represent all points (implementing the temperature and $\mathrm{RH}$ filter), the green crosses represent all points where BASE-noAsia $>50 \mathrm{~cm}^{-3}$, and the number of points is given by $N$. (c) The simulated contribution to particle number concentration due to Asian anthropogenic aerosol as a function of particle diameter, $D_{\mathrm{p}}$, averaged over the year when $\mathrm{N}^{8} 0_{\mathrm{BASE}}-\mathrm{N} 80_{\mathrm{noAsia}}>50 \mathrm{~cm}^{-3}$. (d) Time series of the percent (green) and absolute (black) contribution to N80 due to Asian anthropogenic aerosol.

\subsection{Influence of Asian anthropogenic emissions}

Whistler Peak experiences conditions where trans-Pacific FT air transports anthropogenic aerosol from Asia and influences aerosol size distributions. Figure $6 \mathrm{a}$ and $\mathrm{b}$ show $1: 1$ plots for measured and simulated N14 and N80, respectively, from the BASE and noAsia (Asian anthropogenic emissions turned off) simulations, where the gray crosses represent all points (implementing the temperature and $\mathrm{RH}$ filter as discussed earlier) and the green crosses represent all points where $\mathrm{N} 14_{\mathrm{BASE}}-\mathrm{N} 14_{\text {noAsia }}>50 \mathrm{~cm}^{-3}$ and N80 $\mathrm{BASE}^{-}$ $\mathrm{N} 80_{\text {noAsia }}>50 \mathrm{~cm}^{-3}$, where $50 \mathrm{~cm}^{-3}$ is our criterion for "high Asian anthropogenic influence". Thus, we are using the simulations to characterize periods of high Asian aerosol influence. Comparison of the BASE simulation with the noAsia simulation indicates that Asian anthropogenic aerosol influences N14 and N80 during both clean and polluted periods.

The overall impact that transport from Asia has on the number size distribution at Whistler is shown in Fig. 6c, which shows the simulated contribution to particle number concentration due to Asian anthropogenic aerosol (BASE-noAsia) as a function of particle diameter, $D_{\mathrm{p}}$, averaged over the measurement period when N80 $\mathrm{BASE}^{-}$ $\mathrm{N} 80_{\text {noAsia }}>50 \mathrm{~cm}^{-3}$. There is a negative contribution to particle number concentrations $\left(\mathrm{d} N / \operatorname{dlog}_{10} D_{\mathrm{p}}\right)$ exceeding $200 \mathrm{~cm}^{-3}$ for particle sizes with diameters smaller than approximately $20 \mathrm{~nm}$, and a positive contribution to particle sizes with diameters larger than around $70 \mathrm{~nm}$, not exceeding $50 \mathrm{~cm}^{-3}$. These results imply that the Asian emissions are increasing the concentration of particles larger than about $100 \mathrm{~nm}$ during transport; however, they are significantly decreasing the concentration of particles less than $20 \mathrm{~nm}$. These larger particles are suppressing nucleation and acting as a coagulation sink for smaller particles; both of these effects cause the presence of Asian aerosol emissions in the model to reduce the number of Aitken-mode particles. Figure $6 \mathrm{~d}$ shows a time series of the percent (green) and absolute (black) contribution to N80 due to Asian anthropogenic aerosol. Periods where the contribution to N80 exceeds $30 \%$ correspond generally to colder months and at particle number concentrations less than $800 \mathrm{~cm}^{-3}$, as these are the periods where the BL height is the lowest and Whistler Peak is influenced predominantly by FT air masses carrying Asian anthropogenic aerosol.

\subsection{Influence of North American boreal forest fires}

Whistler Peak also experiences periods of increased concentrations of biomass-burning aerosol. Similar to Fig. 6a and b, Fig. $7 \mathrm{a}$ and $\mathrm{b}$ show $1: 1$ plots for measured and simulated N14 and N80, respectively, from the BASE and noBioB (biomass-burning emissions turned off) simulations. The gray crosses represent all points (implementing the temperature and RH filter as discussed earlier) and the red crosses represent all points where $\mathrm{N} 14_{\mathrm{BASE}}-\mathrm{N} 14_{\text {noBioB }}>100 \mathrm{~cm}^{-3}$ and $\mathrm{N} 80_{\mathrm{BASE}}-\mathrm{N} 80_{\text {noBioB }}>100 \mathrm{~cm}^{-3}$, where $100 \mathrm{~cm}^{-3}$ is our criterion for "high biomass-burning influence". We are using the simulations to characterize periods of high biomass-burning aerosol influence. Comparing the BASE simulation with the noBioB simulation indicates that biomass-burning aerosol influences all particle sizes (N14 and N80), and the biomass-burning emissions contribute to many of the periods with the highest particle number concentrations in both the model and the measurements. This result is consistent with biomass-burning plumes, which contain high number concentrations of Aitken- and/or accumulationmode particles (Janhäll et al., 2010; Sakamoto et al., 2015).

The impact of biomass-burning aerosol on the particle size distribution is quantified in Fig. 7c, which shows the simulated contribution to particle number concentration due to biomass-burning aerosol (BASE-noBioB) as a function of particle diameter, $D_{\mathrm{p}}$, averaged over the year when $\mathrm{N} 80_{\mathrm{BASE}}-\mathrm{N} 80_{\text {noBioB }}>100 \mathrm{~cm}^{-3}$. For particle sizes with $D_{\mathrm{p}}>20 \mathrm{~nm}$, there is a positive contribution to parti- 

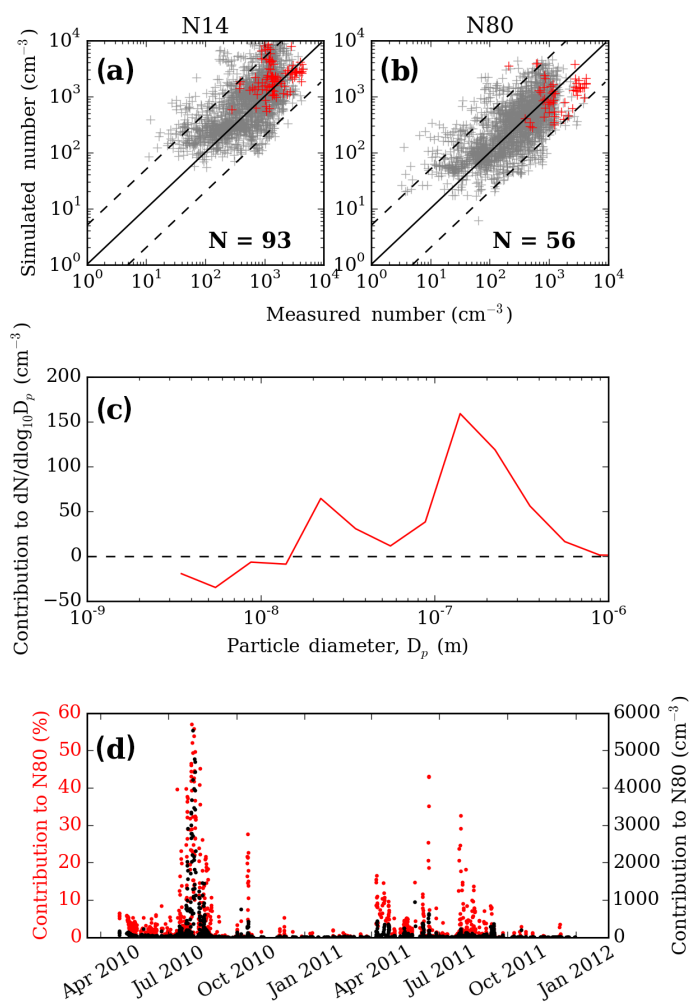

Figure 7. One-to-one plots for measured and simulated (nested resolution) (a) N14 and (b) N80, where the gray crosses represent all points (implementing the temperature and $\mathrm{RH}$ filter), the red crosses represent all points where BASE-noBioB $>100 \mathrm{~cm}^{-3}$, and the number of points is given by $N$. (c) The simulated contribution to particle number concentration due to biomass-burning aerosol as a function of particle diameter, $D_{\mathrm{p}}$, averaged over the year when $\mathrm{N} 80_{\mathrm{BASE}}-\mathrm{N} 80_{\text {noBioB }}>100 \mathrm{~cm}^{-3}$. (d) Time series of the percent (red) and absolute (black) contribution to N80 due to biomass-burning aerosol.

cle number concentrations $\left(\mathrm{d} N / \operatorname{dlog}_{10} D_{\mathrm{p}}\right)$ with enhancements in the accumulation mode exceeding $150 \mathrm{~cm}^{-3}$ between 100 and $200 \mathrm{~nm}$. The size at which this peak occurs is likely sensitive to the emissions size assumed in GEOSChem-TOMAS, which is currently set to a mode centered at $100 \mathrm{~nm}$. Biomass-burning emissions size in aerosol models is uncertain because it is difficult to capture sub-grid aging due to coagulation and chemistry (Sakamoto et al., 2015). There is also a marginal reduction of nucleation-mode particles, which is likely due to an increase in the coagulation sink due to the enhancement of accumulation-mode particles. A clear seasonality of Whistler Peak experiencing biomassburning events is shown in Fig. 7d, which shows a time series of the percent (red) and absolute (black) contribution to N80 due to biomass-burning aerosol. Expectedly, N80 contributions exceeding $25 \%$ and upwards of $5000 \mathrm{~cm}^{-3}$ at Whistler Peak only occur during the summer months (North American forest fire season).

\subsection{High aerosol loading but low biomass-burning/Asian anthropogenic influence}

In addition to the periods with biomass-burning influence, Whistler Peak has periods with high particle number concentrations without influence from biomass-burning emissions. Figure 8 shows 2-day back trajectories (HYSPLIT version 4.9; Draxler and Hess, 1997, 1998; Draxler, 1999) for July 2010 including only times with low biomassburning or Asian anthropogenic influence $\left(\mathrm{N}^{8} 0_{\mathrm{BASE}}-\right.$ $\mathrm{N} 80_{\text {noAsia }}<50 \mathrm{~cm}^{-3}$ and $\mathrm{N} 80_{\text {BASE }}-\mathrm{N} 80_{\text {noBioB }}<100 \mathrm{~cm}^{-3}$ ) and $N 80_{\text {BASE }}>1000 \mathrm{~cm}^{-3}$. Figure 8 is colored by (a) altitude above ground level, (b) surface air temperature, and (c) downwelling insolation. During July 2010, the trajectories of these air parcels with high particle number concentrations advect to Whistler Peak through the heavily wooded (montane and coastal forests) interior of British Columbia at elevations below $1000 \mathrm{~m}$ (Fig. 8a). This region is largely characterized by series of forested valleys with high emissions of biogenic volatile organic compounds known to be precursors for SOA formation. The emissions of biogenic vapors are highly dependent on surface air temperature and downwelling insolation. Increasing surface air temperature and solar insolation yield increases in biogenic emissions (Guenther et al., 2006). Paasonen et al. (2013) and Leaitch et al. (1999) showed that regions influenced by biogenic volatile organic compound (BVOC) emissions have increased concentrations of $\mathrm{CCN}$-sized particles (e.g., N80) with increasing temperature due to high SOA concentrations and increased growth of Aitken-mode particles to these larger sizes. Figure $8 \mathrm{~b}$ and $\mathrm{c}$ show that most of the trajectories experienced warm temperatures (>292 K) and high downwelling insolation $\left(>700 \mathrm{~W} \mathrm{~m}^{-2}\right)$ prior to arriving at Whistler. The advection of relatively warm BL air that has passed over BVOC-generating forests to Whistler Peak is a likely reason for high particle concentrations at Whistler Peak in the absence of biomass-burning influence. However, metropolitan areas such as Vancouver and Seattle could also contribute aerosol to some of the trajectories. The importance of biogenic aerosol during this period was identified as part of the Whistler Aerosol and Cloud Study (e.g., Pierce et al., 2012; Ahlm et al., 2013).

\section{Conclusions}

Continuous high-elevation surface-based aerosol size distribution measurements have been taken by Environment Canada at Whistler Peak $\left(50.06^{\circ} \mathrm{N}, 122.96^{\circ} \mathrm{W}\right.$; $2182 \mathrm{~m}$ a.s.l.), located in the Coast Mountains in southwestern British Columbia. Whistler Peak is influenced by longrange transport of trans-Pacific air masses in the free troposphere (FT) or local boundary-layer (BL) air being lifted thermodynamically or orographically to the mountain peak. In this study, we use measurements from Whistler Peak 

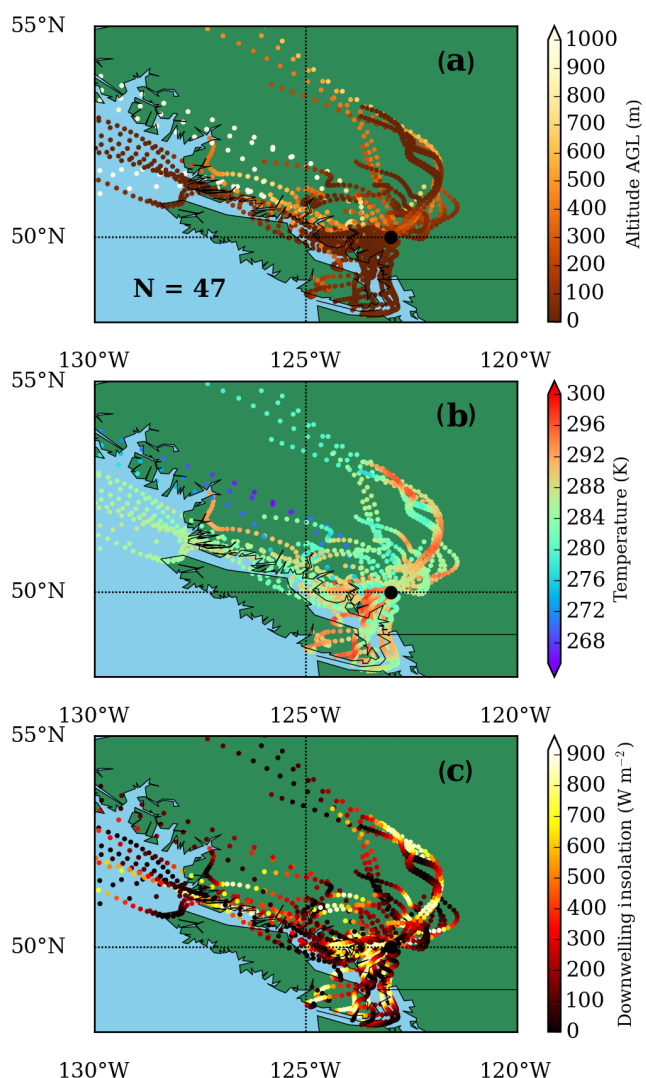

Figure 8. Two-day back trajectories for July 2010 including only times with low biomass-burning or Asian anthropogenic influence $\left(\mathrm{N}_{80} \mathrm{BASE}^{-\mathrm{N} 80_{\mathrm{no}} \mathrm{Asia}}<50 \mathrm{~cm}^{-3}\right.$ and $\mathrm{N}^{-3} 0_{\mathrm{BASE}^{-}}$ $\mathrm{N} 80_{\text {noBioB }}<100 \mathrm{~cm}^{-3}$ ) and $\mathrm{N} 80_{\mathrm{BASE}}>1000 \mathrm{~cm}^{-3}$. The trajectories are colored by (a) altitude above ground level, (b) surface air temperature, and (c) downwelling insolation. The end point of the trajectory is set to $100 \mathrm{~m}$ above ground level. The black circle represents Whistler Peak and the number of back trajectories is given by $N$.

and simulations from the global chemical transport model GEOS-Chem-TOMAS at $4^{\circ} \times 5^{\circ}$ (coarse) and $0.5^{\circ} \times 0.667^{\circ}$ (nested) resolutions in order to investigate the source attribution and processes that shape the aerosol at Whistler Peak.

To compare simulations to measurements at Whistler Peak, it was necessary to develop filtering techniques to determine whether there was BL or FT influence at Whistler Peak. We found that, using the measured temperature at Whistler Peak as a proxy for upslope flow, we could improve our agreement with measurements, and that temperature was a better proxy than a $\mathrm{CN}$ proxy that had been previously used as a proxy for BL air at Whistler (Gallagher et al., 2011), although it is possible that better proxies exist. The best threshold temperature we found was $2^{\circ} \mathrm{C}$ for the coarse simulations and $6{ }^{\circ} \mathrm{C}$ for the nested simulations, with warmer temperatures indicating upslope flow. If the temperature was colder than $2{ }^{\circ} \mathrm{C}\left(6^{\circ} \mathrm{C}\right)$ in the coarse (nested) simulations, the simulated layer corresponding to the actual elevation of Whistler
Peak was used $(1580 \mathrm{~m}(890 \mathrm{~m})$ level above the model surface, $600 \mathrm{~m}(1290 \mathrm{~m}))$. Whistler Peak also often experiences in-cloud conditions when the RH measurements are larger than $90 \%$. When in cloud, activated particles are not measured, so aerosol size distribution measurements should not be used. Therefore, we filter out measurements when the measured RH exceeded $90 \%$. With the inclusion of these two filtering techniques, the model-measurement comparisons of N14 and N80 improved significantly in the coarse (nested) simulations with the slope of the regression improving to $0.44(0.65)$ and $0.67(0.65)$, respectively, $R^{2}$ improving to $0.30(0.40)$ and $0.44(0.46)$, respectively, and log-mean bias improving to $0.08(0.17)$ and $-0.03(0.07)$, respectively.

Due to the high elevation of Whistler Peak, the measurement site is often influenced by long-range transport of Asian anthropogenic aerosol. To investigate this, a base simulation (BASE) was compared to a simulation with Asian anthropogenic emissions turned off (noAsia) at the nested resolution. High Asian influence periods were determined when the difference in particle number concentrations between the BASE simulation and the noAsia simulation exceeded $50 \mathrm{~cm}^{-3}$. The long-range transport of Asian anthropogenic aerosol was found to occur during periods with low total particle number concentrations and increase the number of particles larger than $80 \mathrm{~nm}(\mathrm{~N} 80)$ but decrease the number of smaller particles due to suppression of new-particle formation and increases in coagulation. The influence of Asian anthropogenic aerosol was found to be most prevalent during the winter months, when the BL height is the lowest and long-range transport dominates the aerosol at Whistler Peak.

Whistler Peak experiences BL air influence particularly during summer months, and during fire seasons upslope flow or deep boundary layers can transport biomass-burning aerosol to the peak. To investigate this, the BASE simulation was compared to a simulation with biomass-burning emissions turned off (noBioB) at the nested resolution. Similar to the noAsia comparison, high influence periods were determined when the difference between the BASE simulation and the noBioB simulation exceeded $100 \mathrm{~cm}^{-3}$. Biomassburning aerosol was found to increase particle numbers of sizes larger than $20 \mathrm{~nm}$, particularly at sizes near the biomass-burning source diameters in GEOS-Chem-TOMAS $(100 \mathrm{~nm})$, at Whistler Peak.

Occasionally, Whistler Peak measured N80 in excess of $1000 \mathrm{~cm}^{-3}$ without significant influence from Asian anthropogenic or biomass-burning aerosol. We used back trajectories to investigate these high particle number concentration periods. The air masses during these periods were found to flow at low elevations through forested valleys, when both the temperature and downwelling insolation were high. These conditions are ideal for biogenic emissions and lowvolatility biogenic secondary organic aerosol (SOA) formation. Based on this back-trajectory analysis, it is hypothesized that this possible source of SOA could be a large 
source of condensable material, which could increase particle growth and hence increase N80.

Mountain measurement sites are difficult to simulate in global chemical transport models. By using simple filters on simulated data, we were able to improve modelmeasurement comparisons. We were also able to test the sensitivity of the simulations to Asian anthropogenic emissions and local biomass burning to determine source apportionment at a high-elevation mountain site. These low-cost techniques could be used in other global models to more accurately represent mountain measurement sites, leading to a better understanding of mountain meteorology and chemistry; however, the details of the filtering likely need to be tuned for different models and mountains.

Acknowledgements. Jessica $\mathrm{Ng}$ was supported by the Center for Multiscale Modeling of Atmospheric Processes summer internship program at Colorado State University.

Edited by: B. Ervens

\section{References}

Ahlm, L., Shakya, K. M., Russell, L. M., Schroder, J. C., Wong, J. P. S., Sjostedt, S. J., Hayden, K. L., Liggio, J., Wentzell, J. J. B., Wiebe, H. A., Mihele, C., Leaitch, W. R., and Macdonald, A. M.: Temperature-dependent accumulation mode particle and cloud nuclei concentrations from biogenic sources during WACS 2010, Atmos. Chem. Phys., 13, 3393-3407, doi:10.5194/acp-133393-2013, 2013.

Boucher, O., Randall, D., Artaxo, P., Bretherton, C., Feingold, G., Forster, P., Kerminen, V.-M., Kondo, Y., Liao, H., Lohmann, U., Rasch, P., Satheesh, S. K., Sherwood, S., Stevens, B., and Zhang, X. Y.: Clouds and Aerosols, in: Climate Change 2013: The Physical Science Basis. Contribution of Working Group I to the Fifth Assessment Report of the Intergovernmental Panel on Climate Change, edited by: Stocker, T. F., Qin, D., Plattner, G.-K., Tignor, M., Allen, S. K., Boschung, J., Nauels, A., Xia, Y., Bex, V., and Midgley, P. M., Cambridge University Press, Cambridge, UK and New York, NY, USA, 2013.

Bailey, R., Barrie, L. A., Halsall, C. J., Fellin, P., and Muir, D. C. G.: Atmospheric organochlorine pesticides in the western Canadian Arctic: Evidence of transpacific transport, J. Geophys. Res., 105, 11805-11811, 2000.

Baltensperger, U., Gäggeler, H. W., Jost, D. T., Lugauer, M., Schwikowski, M., Weingartner, E., and Seibert, P.: Aerosol climatology at the high-alpine site Jungfraujoch, Switzerland, J. Geophys. Res., 102, 19707-19715, 1997.

Bodhaine, B. A.: Aerosol measurements during the Mauna Loa Photochemistry Experiment 2, J. Geophys. Res.-Atmos., 101, 14757-14765, 1996.

Clement, A. C., Burgman, R., and Norris, J. R.: Observational and Model Evidence for Positive Low-Level Cloud Feedback, Science, 325, 460-464, 2009.
Collaud Coen, M., Weingartner, E., Furger, M., Nyeki, S., Prévôt, A. S. H., Steinbacher, M., and Baltensperger, U.: Aerosol climatology and planetary boundary influence at the Jungfraujoch analyzed by synoptic weather types, Atmos. Chem. Phys., 11, 5931-5944, doi:10.5194/acp-11-5931-2011, 2011.

Croft, B., Pierce, J. R., and Martin, R. V.: Interpreting aerosol lifetimes using the GEOS-Chem model and constraints from radionuclide measurements, Atmos. Chem. Phys., 14, 4313-4325, doi:10.5194/acp-14-4313-2014, 2014.

D’Andrea, S. D., Häkkinen, S. A. K., Westervelt, D. M., Kuang, C., Levin, E. J. T., Kanawade, V. P., Leaitch, W. R., Spracklen, D. V., Riipinen, I., and Pierce, J. R.: Understanding global secondary organic aerosol amount and size-resolved condensational behavior, Atmos. Chem. Phys., 13, 11519-11534, doi:10.5194/acp-1311519-2013, 2013.

Draxler, R. R.: HYSPLIT4 user's guide, NOAA Tech. Memo. ERLARL-230, NOAA Air Resources Laboratory, Silver Spring, MD, 1999.

Draxler, R. R. and Hess, G. D.: Description of the HYSPLIT 4 modeling system, NOAA Tech. Memo. ERLARL-224, NOAA Air Resources Laboratory, Silver Spring, MD, 1997.

Draxler, R. R. and Hess, G. D.: An overview of the HYSPLIT 4 modeling system of trajectories, dispersion, and deposition, Aust. Meteorol. Mag., 47, 295-308, 1998.

Gallagher, J. P.: Patterns of planetary boundary layer influence at the Whistler Mountain air chemistry observatory: an observational mountain meteorology study, M.Sc. thesis, University of British Columbia, Canada, 132 pp., 2010.

Gallagher, J. P., McKendry, I. G., Macdonald, A. M., and Leaitch, W. R.: Seasonal and Diurnal Variations in Aerosol Concentration on Whistler Mountain: Boundary Layer Influence and Synoptic Scale Controls, J. Appl. Meteorol. Clim., 50, 2210-2222, doi:10.1175/JAMC-D-11-028.1, 2011.

Grant, A. N., Pszenny, A. A. P, and Fischer, E. V.: The 1935-2003 Air Temperature Record from the Summit of Mount Washington, New Hampshire, J. Climate, 18, 4445-4453, 2005.

Guenther, A., Karl, T., Harley, P., Wiedinmyer, C., Palmer, P. I., and Geron, C.: Estimates of global terrestrial isoprene emissions using MEGAN (Model of Emissions of Gases and Aerosols from Nature), Atmos. Chem. Phys., 6, 3181-3210, doi:10.5194/acp-63181-2006, 2006.

Husar, R., Tratt, D. M., Schichtel, B. A., Falke, S. R., Li, F., Jaffe, D., Gassó, S., Gill, T., Laulainen, N. S., Lu, F., Reheis, M. C., Chun, Y., Westphal, D., Holben, B. N., Gueymard, C., McKendry, I., Kuring, N., Feldman, G. C., McClain, C., Frouin, R. J., Merrill, J., DuBois, D., Vignola, F., Murayama, T., Nickovic, S., Wilson, W. E., Sassen, K., Sugimoto, N., and Malm, W. C.: Asian dust events of April 1998, J. Geophys. Res., 106, 1831718330, doi:10.1029/2000JD900788, 2001.

Jaffe, D., Anderson, T., Covert, D., Kotchenruther, R., Trost, B., Danielson, J., Simpson, W., Berntsen, T., Karlsdottir, S., Blake, D., Harris, J., Carmichael, G., and Uno, I.: Transport of Asian air pollution to North America, Geophys. Res. Lett., 26, 711-714, 1999.

Jaffe, D. A., McKendry, I., Anderson, T., and Price, H.: Six "new" episodes of trans-Pacific transport of air pollutants, Atmos. Environ., 37, 391-404, 2003. 
Janhäll, S., Andreae, M. O., and Pöschl, U.: Biomass burning aerosol emissions from vegetation fires: particle number and mass emission factors and size distributions, Atmos. Chem. Phys., 10, 1427-1439, doi:10.5194/acp-10-1427-2010, 2010.

Leaitch, W. R., Bottenheim, J. W., Biesenthal, T. A., Li, S. M., Liu, P. S. K., Asalian, K., Dryfhout-Clark, H., Hopper, F., and Brechtel, F.: A case study of gas-to-particle conversion in an eastern Canadian forest, J. Geophys. Res., 104, 8095-8111, 1999.

Leaitch, W. R., Macdonald, A. M., Anlauf, K. G., Liu, P. S. K., Toom-Sauntry, D., Li, S.-M., Liggio, J., Hayden, K., Wasey, M. A., Russell, L. M., Takahama, S., Liu, S., van Donkelaar, A., Duck, T., Martin, R. V., Zhang, Q., Sun, Y., McKendry, I., Shantz, N. C., and Cubison, M.: Evidence for Asian dust effects from aerosol plume measurements during INTEXB 2006 near Whistler, BC, Atmos. Chem. Phys., 9, 3523-3546, doi:10.5194/acp-9-3523-2009, 2009.

Macdonald, A. M., Anlauf, K. G., Leaitch, W. R., Chan, E., and Tarasick, D. W.: Interannual variability of ozone and carbon monoxide at the Whistler high elevation site: 2002-2006, Atmos. Chem. Phys., 11, 11431-11446, doi:10.5194/acp-1111431-2011, 2011.

McKendry, I. G., Macdonald, A. M., Leaitch, W. R., van Donkelaar, A., Zhang, Q., Duck, T., and Martin, R. V.: Trans-Pacific dust events observed at Whistler, British Columbia during INTEXB, Atmos. Chem. Phys., 8, 6297-6307, doi:10.5194/acp-8-62972008, 2008.

Mu, M., Randerson, J. T., Van der Werf, G. R., Giglio, L., Kasibhatla, P., Morton, D., Collatz, G. J., DeFries, R. S., Hyer, E. J., Prins, E. M., Griffith, D. W. T., Wunch, D., Toon, G. C., Sherlock, V., and Wennberg, P. O.: Daily and 3-hourly variability in global fire emissions and consequences for atmospheric model predictions of carbon monoxide, J. Geophys. Res., 116, D24303, doi:10.1029/2011JD016245, 2011.

Napari, I., Noppel, M., Vehkamäki, H., and Kulmala, M.: Parametrization of ternary nucleation rates for $\mathrm{H}_{2} \mathrm{SO}_{4}-\mathrm{NH}_{3}$ $\mathrm{H}_{2} \mathrm{O}$ vapors, J. Geophys. Res.-Atmos., 107, AAC6.1-AAC6.6, doi:10.1029/2002JD002132, 2002.

Obrist, D., Gannet Hallar, A., McCubbin, I., Stephens, B. B., and Rahn, T.: Atmospheric mercury concentrations at Storm Peak Laboratory in the Rocky Mountains: Evidence for long-range transport from Asia, boundary layer contributions, and plant mercury uptake, Atmos. Environ., 42, 7579-7589, 2008.

Paasonen, P., Asmi, A., Petaja, T., Kajos, M. K., Aijala, M., Junninen, H., Holst, T., Abbatt, J. P. D., Arneth, A., Birmili, W., van der Gon, H. D., Hamed, A., Hoffer, A., Laakso, L., Laaksonen, A., Leaitch, W. R., Plass-Dulmer, C., Pryor, S. C., Raisanen, P., Swietlicki, E., Wiedensohler, A., Worsnop, D. R., Kerminen, V.-M., and Kulmala, M.: Warming-induced increase in aerosol number concentration likely to moderate climate change, Nat. Geosci., 6, 438-442, 2013.

Pierce, J. R., Chen, K., and Adams, P. J.: Contribution of primary carbonaceous aerosol to cloud condensation nuclei: processes and uncertainties evaluated with a global aerosol microphysics model, Atmos. Chem. Phys., 7, 5447-5466, doi:10.5194/acp-75447-2007, 2007.

Pierce, J. R., Riipinen, I., Kulmala, M., Ehn, M., Petäjä, T., Junninen, H., Worsnop, D. R., and Donahue, N. M.: Quantification of the volatility of secondary organic compounds in ultrafine par- ticles during nucleation events, Atmos. Chem. Phys., 11, 90199036, doi:10.5194/acp-11-9019-2011, 2011.

Pierce, J. R., Leaitch, W. R., Liggio, J., Westervelt, D. M., Wainwright, C. D., Abbatt, J. P. D., Ahlm, L., Al-Basheer, W., Cziczo, D. J., Hayden, K. L., Lee, A. K. Y., Li, S.-M., Russell, L. M., Sjostedt, S. J., Strawbridge, K. B., Travis, M., Vlasenko, A., Wentzell, J. J. B., Wiebe, H. A., Wong, J. P. S., and Macdonald, A. M.: Nucleation and condensational growth to CCN sizes during a sustained pristine biogenic SOA event in a forested mountain valley, Atmos. Chem. Phys., 12, 3147-3163, doi:10.5194/acp-12-3147-2012, 2012.

Rosenfeld, D., Lohmann, U., Raga, G. B., O’Dowd, C. D., Kulmala, M., Fuzzi, S., Reissell, A., and Andreae, M. O.: Flood or drought: How do aerosols affect precipitation?, Science, 321, 1309-1313, 2008.

Sakamoto, K. M., Allan, J. D., Coe, H., Taylor, J. W., Duck, T. J., and Pierce, J. R.: Aged boreal biomass-burning aerosol size distributions from BORTAS 2011, Atmos. Chem. Phys., 15, 1633 1646, doi:10.5194/acp-15-1633-2015, 2015.

Singh, H. B., Brune, W. H., Crawford, J. H., Flocke, F., and Jacob, D. J.: Chemistry and transport of pollution over the Gulf of Mexico and the Pacific: spring 2006 INTEX-B campaign overview and first results, Atmos. Chem. Phys., 9, 2301-2318, doi:10.5194/acp-9-2301-2009, 2009.

Spracklen, D. V., Carslaw, K. S., Pöschl, U., Rap, A., and Forster, P. M.: Global cloud condensation nuclei influenced by carbonaceous combustion aerosol, Atmos. Chem. Phys., 11, 9067-9087, doi:10.5194/acp-11-9067-2011, 2011.

Stevens, R. G. and Pierce, J. R.: The contribution of plume-scale nucleation to global and regional aerosol and $\mathrm{CCN}$ concentrations: evaluation and sensitivity to emissions changes, Atmos. Chem. Phys., 14, 13661-13679, doi:10.5194/acp-14-13661-2014, 2014

Streets, D. G., Bond, T. C., Carmichael, G. R., Fernandes, S. D., Fu, Q., He, D., Klimont, Z., Nelson, S. M., Tsai, N. Y., Wang, M. Q., Woo, J.-H., and Yarber, K. F.: An inventory of gaseous and primary aerosol emissions in Asia in the year 2000, J. Geophys. Res., 108, 8809, doi:10.1029/2002JD003093, 2003.

Takahama, S., Schwartz, R. E., Russell, L. M., Macdonald, A. M., Sharma, S., and Leaitch, W. R.: Organic functional groups in aerosol particles from burning and non-burning forest emissions at a high-elevation mountain site, Atmos. Chem. Phys., 11, 6367-6386, doi:10.5194/acp-11-6367-2011, 2011.

Vehkamäki, H., Kulmala, M., Napari, I., Lehtinen, K. E. J., Timmreck, C., Noppel M., and Laaksonen, A.: An improved parameterization for sulfuric acid-water nucleation rates for tropospheric and stratospheric conditions, J. Geophys. Res., 107, 4622, doi:10.1029/2002JD002184, 2002.

Weiss-Penzias, P., Jaffe, D., Swartzendruber, P., Dennison, J. B., Chand, D., Hafner, W., and Prestbo, E.: Observations of Asian air pollution in the free troposphere at Mount Bachelor Observatory during spring of 2004, J. Geophys. Res., 111, D10304, doi:10.1029/2005JD006522, 2006.

Westervelt, D. M., Pierce, J. R., Riipinen, I., Trivitayanurak, W., Hamed, A., Kulmala, M., Laaksonen, A., Decesari, S., and Adams, P. J.: Formation and growth of nucleated particles into cloud condensation nuclei: model-measurement comparison, Atmos. Chem. Phys., 13, 7645-7663, doi:10.5194/acp-13-76452013, 2013. 
Yu, F. and Hallar, G.: Difference in particle formation at a mountaintop location during the spring and summer: Implications for the role of sulfuric acid and organics in nucleation, J. Geophys. Res., 119, 12246-12255, doi:10.1002/2014JD022136, 2014.
Yu, F., Luo, G., Bates, T., B. Anderson, B., A. Clarke, A., Kapustin, V., Yantosca, B., Wang, Y., and Wu, S.: Spatial distributions of particle number concentrations in the global troposphere: Simulations, observations, and implications for nucleation mechanisms, J. Geophys. Res., 115, D17205, doi:10.1029/2009JD013473, 2010. 